Jurnal Penelitian Pendidikan, Psikologi Dan Kesehatan (J-P3K) 2021, Vol. 2 (No. 2) : 118-125

\title{
Peranan Longlife Learning dengan Kemampuan Literasi Pada Pendidikan Kejuruan/Vokasi Ditinjau dari Filosofi Pragmatism Rekonstruksionis
}

\section{The Role of Longlife Learning with Literacy Skills in Vocational/ Vocational Education in terms of the Reconstructionist Pragmatism Philosophy}

\author{
Oktariani ${ }^{(1 *)} \&$ Evri Ekadiansyah(2) \\ (1) Fakultas Psikologi Universitas Potensi Utama, Indonesia \\ (2) Fakultas Teknik dan Ilmu Komputer, Universitas Potensi Utama, Indonesia
}

Disubmit: 06 April 2021; Diproses: 20 April 2021; Diaccept: 17 Juli 2021; Dipublish: 02 Agustus 2021

*Corresponding author: E-mail: oktariani1610@gmail.com

\begin{abstract}
Abstrak
Indonesia berdasarkan tujuan pendidikan kejuruan dalam UU Nomor 20 Tahun 2003 lebih mengarah kepada filosofi esensialisme oleh mahzab Prosser, sedangkan dalam PP 19 Tahun 2005 yang menjelaskan tentang pendidikan kejuruan lebih mengarah kepada filosofinya pragmatisme oleh mahzab Dewey. Konsep Longlife learning (belajar sepanjang hayat) mengenai belajar secara terus menerus dan berkesinambungan (continuinglearning) yang sesuai fase dari perkembangan pada manusia. Sebagai generasi penerus, sangat dibutuhkan proses belajar seumur hidup (longlife learning) ini untuk memenuhi "self interest" yang saat ini menjadi tuntutan hidup mereka, seperti kebutuhan membaca serta latihan keterampilan bagi para pekerja, hal ini sangat membantu untuk menghadapi permasalahan - permasalahan merupakan kunci keberhasilan. Penelitian ini termasuk dalam penelitian kualititaif, dengan metode yang digunakan untuk pengkajian ini adalah studi literatur. Pengumpulan data atau sumber literature dengan menggunakan metode library research dengan berbagai sumber ilmiah dalam bentuk buku, artikel ilmiah serta literature yang sesuai dengan topik yang diambil. Kemudian data atau informasi yang diperoleh dikumpulkan, dianalisis, dan disimpulkan sehingga mendapatkan kesimpulan mengenai studi literatur. Dengan keterampilan literasi ini diharapkan akan membantu mahasiswa untuk bias mengembangkan kemampuan dalam berpikir kritis.
\end{abstract}

Kata Kunci: Longlife Learning; Literasi; Pragmatisme

\begin{abstract}
Indonesia based on the objectives of vocational education in Law Number 20 of 2003 is more directed to the philosophy of essentialism by the Prosser school, while in PP 19 of 2005 which explains vocational education is more directed to the philosophy of pragmatism by the Dewey school. The concept of Longlife learning (lifelong learning) regarding continuous and continuous learning (continuing-learning) which is in accordance with the phases of human development. As the next generation, this long life learning process is really needed to fulfill the "self interest" which is currently the demands of their life, such as the need for reading and skills training for workers, this is very helpful in dealing with problems - problems are key success. This research is included in qualitative research, with the method used for this study is a literature study. Collecting data or literature sources using library research methods with various scientific sources in the form of books, scientific articles and literature that are in accordance with the topics taken. Then the data or information obtained is collected, analyzed, and concluded so as to obtain conclusions regarding the study of literature. With this literacy skill, it is hoped that it will help students to be able to develop abilities in critical thinking.
\end{abstract}

Keywords: Longlife Learning ; Literacy ;Pragmatism

DOI: https://doi.org/10.51849/j-p3k.v2i2.102

Rekomendasi mensitasi :

Oktariani \& Ekadiansyah, E. (2021), Peranan Longlife Learning dengan Kemampuan Literasi Pada Pendidikan Kejuruan/Vokasi Ditinjau dari Filosofi Pragmatism Rekonstruksionis. Jurnal Penelitian Pendidikan, Psikologi dan Kesehatan (J-P3K), 2 (2): 118-125. 


\section{PENDAHULUAN}

Secara umum tujuan utama dari pendidikan kejuruan dan vokasi adalah untuk mempersiapkan tenaga kerja yang terampil. Di Indonesia, istilah pendidikan kejuruan untuk jenjang pendidikan menengah adalah misalnya SMK/MAK dan pendidikan vokasi untuk pendidikan tinggi adaalah Akademi, Sekolah Tinggi, Politeknik, Institut, dan Universitas. Secara yuridis dapat dilihat dalam Undang - Undang Sistem Pendidikan Nasional (Sisdiknas) Nomor 20 Tahun 2003. Pasal 15 UU Sisdiknas.

Pendidikan Teknologi Kejuruan memiliki beberapa istilah di berbagai negara. Menghasilkan terminologi Technical and Vocational Education and Training (TVET) termasuk pendidikan vokasi meliputi pendidikan dan pelatihan formal, nonformal, dan juga informal. Hasil ini merupakan kesepakatan bersama melalui deligasi yang dihadiri perwakilan dari Unseco, International Labour Organization (ILO), dan Unevoc. Maka dari itu dalam TVET, pendidikan dan pelatihan berjalan seirama dimana TVET merupakan pendidikan dan pelatihan dimana tujuannya adalah untuk mempersiapkan tenaga kerja sesuai kebutuhan dan permintaan lapangan kerja dalam hal ini adalah dunia usaha dan industri yang link and match. Praksis pendidikan kejuruan dunia di motori dua tokoh terkemuka yaitu Charles Prosser dan John Dewey.

Di Indonesia berdasarkan tujuan pendidikan kejuruan dalam UU Nomor 20 Tahun 2003 lebih mengarah kepada filosofi esensialisme oleh mazab Prosser, sedangkan dalam PP 19 Tahun 2005 yang menjelaskan tentang Pendidikan kejuruan lebih mengarah kepada filosofinya pragmatisme oleh mazab Dewey. Perubahan-perubahan yang terjadi dalam pembelajaran Abad XXI memberi tantangan pada TVET dimana terjadinya pergeseran paradigma pengembangan sumber daya manusia melalui revolusi teknologi informasi dan komunikasi. Menurut Sudira (2018), Indonesia dan seluruh dunia dihadapkan pada tantangan perubahan lingkugan kerja dan cara kerja yang semakin disrutif di era revolusi industri 4.0.

Implementasi pendidikan 4.0 ini membutuhkan keterampilan baru sehingga penyiapan SDM sebagai lulusan dari kejuruan dan vokasi harus memilki kompetensi sesuai bahkan memiliki multi kompetensi dengan perkembangan teknologi menjadi sebuah keharusan. Maka dari pada itu peran TVET sebagai pendidikan dan pelatihan harus mampu untuk menghadapi perubahan tantangan tersebut melalui muatan pembelajaran Abad XXI dan menyesuaikan dengan perubahan di era industri 4.0.

Pembelajaran sepanjang hayat (longlife learning) pada dasarnya merupakan suatu konsep pembelajaran yang ditujukan untuk memenuhi kebutuhan belajar (learning needs), dan kebutuhan pendidikan (education needs). Hal ini sejalan dengan pendapat Abraham Maslow, yang dikenal dengan teori hierarki piramida kebutuhan hidup manusia (human needs hierarky) dimana manusia memiliki 5 (lima) tingkatan kebutuhan yaitu: 1) Basic needs, 2) Safety needs, 3) Psikhological needs, 4) Esteem needs, 5) Actualization needs (Abisyamwahidin, 2008). Dari pendapat tersebut selanjutnya dijelaskan bahwa 
Basic needs sebagai kebutuhan dasar manusia terbagi lagi kedalam 3 (tiga) kebutuhan yang meliputi: kebutuhan hidup (life needs), kebutuhan belajar (learning needs), dan kebutuhan pendidikan (education needs). Dari pernyataan tersebut jelas bahwa manusia tidak dapat lepas dari belajar dan pendidikan, maka kebutuhan belajar menjadi sangat dirasakan sekali sehingga kondisi ini menjadi salah satu perhatian seluruh dunia.

Konsep belajar sepanjang hayat (lifelong learning) adalah belajar yang dilakukan secara terus menerus dan berkesinambungan (continuous learning) dari buaian sampai akhir hayat, tergantung pada tingkat perkembangan manusia. Proses pendidikan ini meliputi bentuk - bentuk pembelajaran informal, nonformal dan formal, baik dalam keluarga maupun di sekolah, di tempat kerja dan dalam kehidupan bermasyarakat.

Ada beberapa alasan konsep belajar sepanjang hayat, salah satunya dikemukakan oleh Paul Lengrand. Dalam bukunya "An Introduction to Lifelong Learning", Paul mengatakan bahwa banyak tantangan dalam berbagai bentuk dan variasi, baik di negara maju maupun di negara berkembang, yang membutuhkan pendidikan untuk ditransformasikan menjadi pembelajaran sepanjang hayat. Tantangan tersebut antara lain; kecepatan perubahan, ekspansi demografi, inovasi ilmiah dan teknologi, tantangan politik, krisis informasi dan gaya hidup. Pemikiran yang dikemukakan oleh Paul Lengrand ini kemudian menjadi acuan UNESCO dalam menawarkan konsep pendidikan seumur hidup (dalam Sanapiah, 1981).

Menguasai konsep belajar sepanjang hayat membutuhkan keterampilan membaca. Dimana literasi adalah kemampuan seseorang untuk membaca dan menulis. Pemerolehan keterampilan membaca merupakan indikator penting untuk meningkatkan keberhasilan generasi saat ini. Penciptaan keterampilan membaca harus dilakukan sesegera mungkin, karena merupakan sumber utama dalam membangun bangsa yang cerdas dan berbudaya. Pelatihan kejuruan efektif bila setiap siswa memperoleh manfaat dari minat, pengetahuan, dan keterampilan mereka pada tingkat tertinggi, yaitu keterampilan atau kemampuan membaca dan menulis.

Keterampilan literasi sangat memiliki pengaruh yang penting untuk keberhasilan siswa. Keterampilan literasi yang baik akan sangat membantu siswa untuk memahami informasi lisan maupun tertulis. Di dalam kehidupan, menguasai literasi juga sangat penting untuk mendukung meningkatkan kompetensikompetensi yang dimiliki.

Kompetensi akan bertambah bila siswa dapat menguasai literasi atau dapat diartikan siswa melek serta bisa memilah informasi yang mendukung keberhasilan hidup siswa. Kesadaran berliterasi sangat mendukung keberhasilan seseorang dalam menangani dan menyelesaikan berbagai persoalan. Melalui kemampuan literasi ini, seseorang tidak saja memperoleh ilmu pengetahuan tetapi juga bisa menjadikan pengalaman dan pengetahuan mereka yang menjadi rujukan di masa yang akan datang. 


\section{METODE PENELITIAN}

Penelitian ini termasuk dalam penelitian kualititaif, dengan metode yang digunakan untuk pengkajian ini adalah studi literatur. Pengumpulan data atau sumber literature dengan menggunakan metode library research dengan berbagai sumber ilmiah dalam bentuk buku, artikel ilmiah serta literature yang sesuai dengan topik yang diambil. Kemudian data atau informasi yang diperoleh dikumpulkan, dianalisis, dan disimpulkan sehingga mendapatkan kesimpulan mengenai studi literatur.

\section{HASIL DAN PEMBAHASAN}

Aristoteles

(382-322SM)

mendefinisikan

filsafat sebagai pengetahuan tentang kebenaran. Filsafat juga diartikan sebagai usaha mendeskripsikan sifat dasar yang terdalam dan sesungguhnya dari kenyataan (Jalius Jama, 2010). Filosofi Pendidikan kejuruan di Indonesia mengacu kepada teori Prosser tertanam dalam kurikulum berbasis kompetensi yang berkenaan dengan kompetensi kerja di industri.

Perspektif filosofi esensialisme kurikulum dan pembelajaran dikembangkan berdasarkan kebutuhan bisnis dunia usaha dan industri yang juga tercermin pada Kerangka Kualifikasi Nasional Indonesia (KKNI) di Indonesia saat ini. Sedangkan melalui pengelompokkan program normatif, adaptif, dan produktif yang ada pada pendidikan kejuruan mengandung makna pragmatis dari teorinya dewey. Pembelajaran dalam filosofi pragmatisme mengkonstruksi pengetahuan berdasaran pengetahuan sebelumnya, yaitu mampu memecahkan

masalah

dalam

mempersiapkan kehidupan.

Filosofi

pragmatism rekonstruksionis strand, tujuan TVET untuk melakukan transformasi masyarakat untuk menjadi masyarakat demokratis, belajar organisasi, bersifat proaktif, tidak mengekalkan diri hanya pada praktik-praktik ditempat dunia kerja saja, mengadopsi isu dan masalah ketidakadilan dan ketidak merataan terhadap masalah-masalah dunia kerja.

Filosofi pragmatisme merupakan filosofi yang dianggap sesuai diterapkan pada TVET masa depan (Rojewski, 2009). Karena filosofi pragmatisme mendudukkan TVET sebagai pendidikan yang bertujuan untuk memenuhi kebutuhan individu dalam memenuhi seluruh kebutuhan hidupnya. Selain itu juga sejalan dengan karakteristik pembelajaran Abad XXI, dimana karakteristik filosofi pragmatisme menekankan pemecahan masalah berpikir tingkat tinggi, filosofi pragmatisme ini juga meletakkan pendidikan sebagai interaksi aktif memandirikan peserta didik dalam belajar memecahkan masalah.

Para filsuf yang berhubungan dengan pragmatisme yakni Peirce yang dipandang sebagai penggagas pragmatisme, James sebagai pengembangnya dan Dewey yang menerapkan pragmatisme. Aliran pragmatisme mempunyai relevansi yang tinggi dalam pendidikan kejuruan dalam menumbuhkan kemampuan peserta didik untuk berpikir kritis, mandiri dan mampu mengatasi permasalahan-permasalahan yang terjadi dalam hidupnya.

Dalam aliran filosofi pragmatism rekonstruksionis pengajar memberi 
kesempatan kepada peserta didik untuk belajar dari lingkungan sosial untuk belajar dimasyarakat, belajar berorganisasi yang nyata, ikut serta belajar yang tidak hanya dilingkup di sekolah saja, namun juga diluar sekolah misalnya industri sehingga mampu untuk memecahkan permasalahan yang ada di masyarakat maupun di dunia kerja. Berdasarkan dari penjelasan tersebut filosofi pragmatism rekonstruksionis menjadi salah satu pendukung TVET terutama di era perkembangan teknologi saat ini di era revolusi indutsri 4.0 dengan pembelajaran abad XXI yakni abad yang banyak mengalami perubahan.

Pendidikan seumur hidup (LongLife Learning) adalah suatu konsep, suatu ide (gagasan pokok) dalam konsep ini bahwa pendidikan tidak saja berlangsung selama seseorang belajar di lembaga lembaga pendidikan formal: tetapi bahwa seseorang masih dapat memperoleh pendidikan, jika individu bersekolah setelah individu selesai menjalani pendidikan formal. Pendidikan seumur hidup merumuskan suatu asas bahwa pendidikan adalah suatu proses yang terus menerus (kontinu) dari bayi sampai meninggal dunia.

Pendidikan sepanjang hayat atau pendidikan seumur hidup merupakan sebuah sistem konsep pendidikan yang menjelaskan secara keseluruhan peristiwa kegiatan belajar-mengajar yang berlangsung di keseluruhan kehidupan manusia. Pendidikan sepanjang hayat sangat memandang jauh ke depan, dan berusaha untuk menghasilkan manusia dan masyarakat yang baru, yang merupakan suatu proyek masyarakat yang sangat besar. Pendidikan sepanjang hayat asas pendidikan yang cocok bagi orangorang yang hidup dalam dunia transformasi dan informasi yang berkembang sangat cepat, yaitu masyarakat modern. Dimana manusia harus bisa menyesuaikan dirinya secara terus menerus dengan situasi yang baru.

Pendidikan sepanjang hayat merupakan jawaban terhadap kritik-kritik yang dilontarkan pada sekolah. Sistem sekolah tradisional mengalami kesukaran dalam menyesuaikan diri dengan perubahan kehidupan yang sangat cepat dalam abad terakhir ini, dan tidak dapat memenuhi kebutuhan manusia yang semakin meningkat. Kebutuhan manusia yang sangat meningkat itulah yang memberikan pengaruh besar terhadap masalah-masalah pendidikan dan proses pendidikan akan terus berjalan sejalan dengan semua kebutuhan manusia yang semakin meningkat tersebut. Karakteristik pendidikan sepanjang hayat diantaranya adalah sebagai berikut (dalam Wahyuddin, 2016):

a) Hidup, seumur hidup, dan pendidikan menjadi 3 istilah pokok yang menjadi penentu lingkup dan makna pendidikan sepanjang hayat.

b) Pendidikan menjadi tidak selesai setelah berakhirnya masa sekolah formal, tetapi sebuah proses yang berlangsung sepanjang hidup.

c) Pendidikan sepanjang hayat tidak hanya diartikan sebagai pendidikan untuk orang dewasa, tetapi juga mencakup serta memadukan semua tahap pendidikan baik itu pendidikan dasar, menengah, dan sebagainya.

d) Pendidikan sepanjang hayat mencakup pola-pola pendidikan formal maupun pendidikan non formal, baik 
kegiatan belajar yang terencana maupun kegiatan belajar incidental.

Pada awalnya, literasi dimaknai sebagai suatu keterampilan membaca dan menulis, tetapi dewasa ini pemahaman tentang literasi semakin meluas maknanya. Pemahaman saat ini mengenai makna literasi melingkupi kemampuan membaca, memahami, dan mengapresiasi berbagai bentuk komunikasi secara kritis, yang meliputi bahasa lisan, komunikasi tulis, komunikasi yang terjadi melalui media cetak atau pun elektronik (Wardana dan Zamzam, 2014). Echols \& Shadily (2003) mengemukakan bahwa secara harfiah literasi berasal dari kata literacy yang berarti melek huruf. Sementara itu Kuder \& Hasit (2002) mengemukakan literasi merupakan semua proses pembelajaran baca tulis yang dipelajari seseorang termasuk di dalamnya empat keterampilan berbahasa (mendengar, berbicara, membaca, dan menulis).

Menurut Wells (dalam Heryati, dkk 2010) terdapat empat tingkatan literasi, yaitu performative, functional, informational, dan epistemic. Literasi tingkatan satu hanya sekadar mampu membaca dan menulis. Literasi tingkatan dua dapat menunjukkan kemampuan menggunakan bahasa untuk keperluan hidup atau skill for survival (seperti membaca manual, mengisi formulir, dsb). Literasi tingkatan tiga bisa menunjukkan kemampuan untuk mengakses pengetahuan. Literasi tingkatan empat mempunyai kemampuan untuk mentransformasikan pengetahuan. Literasi menjadi kecakapan hidup yang membuat manusia dapat berfungsi maksimal dalam masyarakat. Dimana kecakapan hidup bersumber dari kemampuan untuk dapat memecahkan masalah melalui kegiatan berpikir secara kritis.

Selain itu, literasi juga merupakan refleksi penguasaan dan apresiasi budaya. Masyarakat yang berbudaya merupakan masyarakat yang dapat menanamkan nilai-nilai positif sebagai upaya aktualisasi dirinya. Aktualisasi diri dapat terbentuk melalui interpretasi, yaitu kegiatan untuk mencari dan membangun makna kehidupan. Hal tersebut dapat dicapai melalui penguasaan literasi yang baik.

$$
\text { Cara sederhana menguasai }
$$

kemampuan literasi adalah dengan menanamkan kebiasaan membaca. Membaca akan memberikan manfaat bagi seseorang, yaitu menambah wawasan dan pengetahuan. Menurut Sumardi (2011), fondasi untuk membangun penguasaan semua ilmu adalah kesenangan dan kebiasaan membaca. Kegemaran membaca adalah kegiatan positif yang akan membuat seseorang semakin pandai daripada seseorang yang tidak memiliki kebiasaan membaca.

Selain itu, makna literasi juga berkembang untuk mengharuskan generasi saat ini melek informasi. Melek informasi dapat diistilahkan dengan literasi informasi. Literasi informasi dapat diartikan sebagai keberaksaraan informasi atau kemelekan informasi. American Library Association (ALA) mendefinisikan literasi informasi sebagai "information literacy is a set of abilities requiring individuals to recognize when information is needed and have the ability to locate, evaluate, and use effective needed information". Definisi tersebut dapat diartikan bahwa literasi informasi 
berperan sebagai alat untuk dapat memilah informasi yang bermanfaat. Dimana informasi akan disaring dengan tujuan untuk efisien ke dalam berbagai aspek selama proses pencarian informasi. Jadi, dapat disimpulkan bahwa kemampuan berliterasi menjadikan generasi muda yang lebih cakap di dalam memilih keluwesan informasi.

\section{SIMPULAN}

Di Indonesia pendidikan kejuruan untuk jenjang sekolah menengah kejuruan dan pendidikan vokasi untuk pendidikan tinggi. Tokoh pendidikan kejuruan dunia di motori oleh dua tokoh terkemuka yaitu Charles Prosser dan John Dewey. Secara filosofis tujuan pendidikan vokasi yakni esensialisme, pragmatis, dan pragmatis rekonstruksi.

Di Indonesia sendiri pada pendidikan kejuruan lebih cendrung mengarah penggunaan mahzab Prosser melalui filosfi esensialisme dan mahzab Dewey filosofi pragmatis. Perubahanperubahan yang terjadi dalam pembelajaran Abad XXI memberi tantangan pada TVET dimana terjadinya pergeseran paradigma pengembangan sumber daya manusia melalui revolusi teknologi informasi dan komunikasi, pada kaspitas ini TVET cenderung kefilosofi pragmatism dalam menghadapi masa depan, dan pragmatis rekonstruksi yang berkaitan dengan perkembangan teknologi.

Revolusi industri 4.0 yang identik dengan perkembangan teknologi yang super cepat, mau tidak mau pendidikan kejuruanpun harus mampu menghadapi transisi ini, maka sangat diperlukannya pembelajaran yang mencakup kompetensi
Abad XXI dan selaras dengan peranan TVET sebagai pendidikan dan pelatihan yang tujuanya mempersiapkan tenaga kerja sesuai kebutuhan dunia kerja.

Pentingnya belajar dari dan dalam dunia kehidupan nyata tidak terbatas pada upaya untuk memiliki dan meningkatkan pengetahuan, keterampilan, sikap, dan aspirasi saja. lebih jauh dari itu kegiatan belajar mencakup segi-segi kehidupan yang lebih luas seperti nilai keagamaan, hubungan sosial, adat istiadat, dan norma-norma yang berkembang dalam masyarakat. Kegiatan belajar diperlukan pula untuk menyesuaikan diri dengan perubahan positif yang terus berkembang dalam kehidupan.

$\begin{array}{ccc}\text { Dengan } & \text { kata lain } & \text { kegiatan } \\ \text { pemberdayaan } & \text { masyarakat } & \text { berbasis }\end{array}$ longlife learning adalah untuk menyiapkan diri guna mencapai suatu kehidupan yang lebih baik di masa yang akan datang. Sebagai generasi penerus, membutuhkan pendidikan seumur hidup (longlife learning) ini dalam rangka pemenuhan "self interest" yang merupakan tuntutan hidup mereka sepanjang masa, seperti kebutuhan akan baca tulis bagi mereka umumnya dan latihan keterampilan bagi para pekerja, sangat membantu mereka untuk menghadapi situasi dan persoalan persoalan penting yang merupakan kunci keberhasilan.

Untuk mendukung keberhasilan ini diperlukan keterampilan literasi, yaitu merupakan kemampuan seseorang yang berhubungan dengan kemampuan seseorang dalam membaca, menulis, berbicara, dan mengolah informasi yang diperoleh sampai kepada menyelesaikan permasalahan yang dihadapi dalam 
kehidupan sehari-hari. Dimana keterampilan literasi ini diharapkan akan membantu siswa dalam mengembangkan kemampuan dalam berpikir kritis. Dimana kemampuan berpikir kritis ini dibutuhkan di dalam dunia kerja, sehingga dapat membantu mereka untuk menghadapi situasi dan persoalan - persoalan penting dalam dunia kerja.

\section{DAFTAR PUSTAKA}

Kuder, S. J., \& Hasit, C. (2002). Enhancing literacy for all students. Prentice Hall.

Kaminski, R. A., \& Good III, R. H. (1998). Assessing early literacy skills in a ProblemSolving model: Dynamic Indicators of Basic Early Literacy Skills.

Jama Jalius (2010). Dialog Seminar Filsafat Pendidikan: Program Pasca Sarjana Fakultas Teknik Universitas Negeri Padang

Verawardina, U., \& Jama, J. (2018). Philosophy TVET di era derupsi revolusi industri 4.0 di Indonesia. Jurnal Filsafat Indonesia, 1(3), 104-111.

Rojewski, J. W. (2009). A conceptual framework for technical and vocational education and training. In International handbook of education for the changing world of work (pp. 19-39). Springer, Dordrecht.

Faisal, S. (1981). Pendidikan Luar Sekolah; Di Dalam Sistem Pendidikan dan Pembangunan Nasional. Surabaya: Usaha Nasional.

Sudira, P. (2016). TVET abad XXI: Filosofi, teori, konsep, dan strategi pembelajaran vokasional. Yogyakarta: UNY.

Sudira, P. (2012). Filosofi dan teori pendidikan vokasi dan kejuruan. Yogyakarta: UNY.

Ali, W. L., \& Zamzam, A. (2014). Strategi Peningkatan Kemampuan Literasi Siswa Di Madrasah. Jurnal Ilmiah Widya Pustaka Pendidikan, 2(3), 248-258.

Wahyuddin, W. (2017). Pendidikan Sepanjang Hayat Menurut Perspektif Islam. SAINTIFIKA ISLAMICA: Jurnal Kajian Keislaman, 3(02), 191-208.

Oktariani, O., \& Ekadiansyah, E. (2020). Peran Literasi dalam Pengembangan Kemampuan Berpikir Kritis. JURNAL PENELITIAN PENDIDIKAN, PSIKOLOGI DAN KESEHATAN (J-P3K), 1(1), 23-33. 